\title{
Karadut tohumlarının çimlenmesi üzerine prolin ve sıcaklık uygulamalarının etkileri
}

\author{
Effects of proline and temperature applications on germination of black mulberry seeds
}

\author{
Emel KAÇAL ${ }^{1 \mathscr{P}}$ (D) Oğuzhan ÇALIŞKAN² ${ }^{\mathbb{D}}$, Arif ATAK $^{3}$ (D) Melih AYDINLI $^{1}$, \\ Gökhan ÖZTÜRK ${ }^{1}$ (D) Alamettin BAYAV ${ }^{1}$ (D)
}

${ }^{1}$ Republic of Turkey, Ministry of Agriculture and Forestry, Fruit Research Institute, Eğirdir, ISPARTA

${ }^{2}$ Hatay Mustafa Kemal University, Faculty of Agriculture, Department of Horticulture, Antakya-Hatay, Turkey.

${ }^{3}$ Republic of Turkey, Ministry of Agriculture and Forestry, Atatürk Horticultural Central Research Institute, YALOVA

MAKALE BILGISI / ARTICLE INFO

\section{Makale tarihçesi / Article history:}

DOI: $10.37908 /$ mkutbd.722437

Geliş tarihi /Received:18.04.2020

Kabul tarihi/Accepted:06.05.2020

\section{Keywords:}

Morus nigra, dormancy, proline, seed germination rate

Corresponding author: Emel KAÇAL

$\bowtie$ : emel.vural@gmail.com

\section{Ö ZET / A B STR A C T}

Atıf / Citation: Kaçal M, Çalışkan O, Atak A, Aydınlı M, Öztürk M, Bayav A (2020) Karadut tohumlarının çimlenmesi üzerine prolin ve sıcaklık uygulamalarının etkileri. MKU. Tar. Bil. Derg. 25(2) : 181-188. DOI: 10.37908/mkutbd.722437

\section{GiRiş}

Dut, Anadolu'nun orijin alanları içerisinde yer alan ve farklı ekolojilerde yetiştiriciliği yapılan geleneksel meyve türlerinden biridir (Ağaoğlu ve ark., 2001). Ülkemizde genellikle taze tüketilmekle birlikte, pekmez, reçel, pestil yapımında da kullanılmaktadır. Süs bitkisi olarak peyzaj alanlarında kullanımı da yaygındır (Ercişli ve Orhan, 2007). Ercişli (2004) ülkemizde yetiştirilen dutların \%95'inin Morus alba (beyazdut), \%3'ünün Morus rubra 
(mordut) ve \%2'sinin Morus nigra (karadut) türlerinden oluştuğunu belirtmiştir. Bununla birlikte, karadutun insan sağlığı üzerine (Aulifa ve ark., 2017; Rodrigues ve ark., 2019) olan olumlu etkilerinin ortaya çıkarılmasıyla, koyu renkli dut türleri üzerinde hem yetiştiricilik hem de ıslah çalışmaları konusunda yapılan araştırmaların (EI Obeidy, 2005; Chang, 2008; Vijayan ve ark., 2012; Türemiş ve ark., 2017) arttığı görülmektedir.

Dut türleri genel olarak çelikle kolay çoğaltılmakla birlikte, karadutun çelikle çoğaltma oranının düşük olması nedeniyle aşı ile çoğaltılmak zorunda kalınması ve bu durumda ise diğer dut türleriyle yaşanan aşı uyuşmazlığı problemine çözüm olarak çöğür anaçlarına ihtiyaç duyulması, tohumla çoğaltmayı zorunlu hale getirmektedir (Erdoğan ve Aygün, 2006; Yıldız ve ark., 2009). Ayrıca, dutta melezleme ıslahı çalışmalarında meyve kalite ve verim bakımından üstün özellikli yeni bireylerin elde edilmesinde tohum kaynağı kullanılmaktadır.

Tohum çimlenmesi içsel (özellikle absisik asit gibi hormonlar) ve dışsal faktörler (tohumun kabuğu, uygun olmayan sıcaklık ve nem) tarafından etkilenmektedir (Hartmann ve ark., 2002). Tohumun dinlenmede kalmasını etkileyen bu faktörlerin giderilmesi için katlama, hormon uygulamaları, aşındırma, tohum kabuğunun çıkarılması, yüksek veya düşük sıcaklık uygulamaları, sıcak su uygulaması ve suda bekletme gibi yöntemler kullanılmaktadır (Gerçekçioğlu ve Çekiç, 1999; Al Absi, 2010; Çalışkan ve ark., 2012; Gündüz ve ark., 2019; Bozdoğan ve ark., 2018). Bugüne kadar dut üzerinde yapılan çimlendirme çalışmalarında $25^{\circ} \mathrm{C}$ sıcaklıkta farklı uygulamaların gerçekleştirildiği görülmektedir (Koyuncu, 2005; Gündüz ve ark., 2019). Bununla birlikte, kontrollü koşullarda tohum çimlendirmesi için kullanılan sıcaklığın türlere göre değiştiği bilinmekte ve en uygun sıcaklık belirlendikten sonra farklı uygulamaların yapılması gerekmektedir. Nitekim Gosling (2007), dut tohumlarının derin dormansi özelliğine sahip olması nedeniyle çimlenme için ilave uygulamalara ihtiyaç duyulduğunu bildirmiştir.

Koyuncu (2005), karadut tohumlarında $4^{\circ} \mathrm{C}^{\prime}$ de 100 gün katlama sonrasında tohum çimlenmesinin \%88'e kadar yükseldiğini ancak kontrol tohumlarında \%33 oranında çimlenme olduğunu bildirmiştir. Benzer olarak Gosling (2007), karadut tohumlarında çimlenme oranının oldukça düşük olduğunu ve $4^{\circ} \mathrm{C}^{\prime}$ de, yaklaşık 2-4 aylık bir katlama yapılmasının gerektiğini belirtmiştir.

Proteinojenik bir aminoasit olan prolin, bitkilerde kuraklık, tuzluluk, ağır metal, düşük sıcaklık ve UV radyasyonu gibi stres koşullarına tepki olarak sentezlenerek bitkilerin strese karşı toleranslarını artırmakta (Hayat ve ark., 2012; Aliniaeifard ve ark.,
2016), çiçeklenme ve bitki gelişiminde hem bir metabolit hem de bir sinyal molekülü olarak rol oynayabilmektedir (Mattioli ve ark., 2009). Stresin olmadığı koşullarda da farklı bitki türlerinin çiçek, çiçek tozu ve tohum gibi üretken dokularında prolin birikiminin arttığı belirtilmiştir (Schwacke ve ark., 1999). Prolinin, alt hücre yapılarının dengelenmesine, serbest radikallerin temizlenmesine ve hücresel redoks potansiyelinin tamponlanmasına katkıda bulunduğu (Kaur ve Asthir, 2015) ve bitki gelişiminde önemli rol oynayan birçok hücre duvarı proteininin önemli bir belirleyicisi olduğu (Kavi Kishor ve ark., 2015) düşünülmektedir. Ayrıca prolin, kuraklık ve tuzluluk gibi abiyotik stres koşulları altında tohum çimlenmesini teşvik edebilmektedir. Prolinin bu etkisi, şekerkamışı (Ghaffari ve Tadayon, 2018), pirinç (Singh ve ark., 2018), kavun (Kaur ve Gupta, 2017) ve domateste (Kaur, 2017) bildirilmiştir.

Bu çalışmada prolin ve sıcaklık uygulamalarının karadut tohumlarının çimlenmesi üzerine etkilerinin araştırılması amaçlanmıştır.

\section{MATERYAL ve YÖNTEM}

\section{Materyal}

Çalışmada, bitkisel materyal olarak Eğirdir yöresinde doğal yayılış gösteren, sağlıklı, yaklaşık 25 yaşı karadut genotipi kullanılmıştır. Tohum eldesi için meyveler, 02.07.2018 (orta dönem) tarihinde hasat edilmiştir. Hasat edilen meyvelerin ortalama meyve eni, meyve boyu ve meyve ağırlığı değerleri sırasıyla $16.64 \mathrm{~mm}$, $25.26 \mathrm{~mm}$ ve $5.00 \mathrm{~g}$ olarak belirlenmiştir. Bir meyvedeki tohum sayısı ise ortalama 22 adettir. Taze meyvelerin hafifçe ezilmesiyle meyveden çıkarılan tohumlar, yıkanarak meyve etinden tamamen ayrılmış, oda sıcaklığında bir gün süreyle kurutulduktan sonra üniform yapıda, canlı ve sağlam olanlar, çimlenme uygulamaları yapılana kadar $4^{\circ} \mathrm{C}^{\prime}$ deki iklim dolabında muhafaza edilmiştir.

\section{Yöntem}

\section{Çimlendirme uygulamaları}

Tohumlar çimlendirme çalışmalarından önce \%1'lik çamaşır suyu ile 5 dakika boyunca steril edilmiş ve sonrasında saf su ile yıkanmışlardır. Çimlenmeyi teşvik etmek amacıyla, tohumlar $1 \mathrm{mM}, 5 \mathrm{mM}, 10 \mathrm{mM}$ ve 15 $\mathrm{mM}$ prolin (L-Proline Cas-No:147-85-3, Merck) çözeltilerinde ve kontrol grubunda ise suda olmak üzere 24 saat süre ile oda sıcaklığında bekletilmişlerdir. Bu sürenin sonunda, $59.52 \mathrm{~mm}$ çap ve $14.11 \mathrm{~mm}$ yüksekliğe sahip steril petrilere, 3 tekerrürlü ve her tekerrürde 25 adet olacak şekilde yerleştirilmişlerdir. Tohum çimlendirme çalışmaları, karanlık koşullarda $15^{\circ} \mathrm{C}, 20^{\circ} \mathrm{C}$, 
$25^{\circ} \mathrm{C}$ ve $30^{\circ} \mathrm{C}$ sıcaklıklardaki bitki büyüme kabinlerinde gerçekleştirilmiştir. Çimlenme, günlük olarak gözlenmiştir. Çimlenmenin durduğu 17. güne kadar çimlenen tohumlar her gün sayılarak kaydedilmiş ve kök uzunlukları $(\mathrm{mm})$ ölçülmüştür. Radisil çıkışı görülen $(2 \mathrm{~mm})$ tüm tohumlar çimlenmiş olarak kabul edilmiştir. Tohumlarda çimlenme yüzdesinin belirlenmesinde "Çimlenen tohum sayısı/Toplam tohum sayısı x 100" eşitliğinden yararlanılmıştır. Ortalama çimlenme süresinin hesaplanmasında ise Bewley ve Black (1994)'in

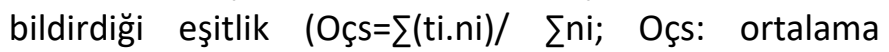
çimlenme süresi, ti: testin başlangıcından itibaren geçen süre (gün), ni: ti gündeki çimlenen tohum sayısı) kullanılmıştır.

\section{Verilerin değerlendirilmesi}

Çalışma, tesadüf parselleri deneme desenine göre kurulmuş, uygulamalar arasındaki farklılık JMP 13 paket programında Duncan Çoklu Karşılaştırma Testi ile $\mathrm{P}<0.05$ güven seviyesinde test edilmiş, regresyon analizi ile de en yüksek tohum çimlenmesinin gerçekleştiği sıcaklıklar belirlenmiştir.

\section{BULGULAR ve TARTIŞMA}

Karadut tohumlarının çimlenme oranı üzerine sıcaklık ve prolin uygulamalarının etkisine ait veriler Şekil 1 ve Şekil 2 'de sunulmuştur. Kontrol grubunda yer alan tohumlarda sıcaklık uygulamalarına bağlı olarak çimlenme oranı istatistiksel olarak önemli farklılıklar göstermiştir. En yüksek tohum çimlenmesi \%70.67 ile $20^{\circ} \mathrm{C}^{\prime}$ de gerçekleşmiştir (Şekil 1). Bunu sırasıyla, $30^{\circ} \mathrm{C}$ (\%41.09) ve $25^{\circ} \mathrm{C}(\% 37.33)$ izlemiştir. En düşük tohum çimlenmesi ise $\% 28.00$ ile $15^{\circ} \mathrm{C}$ 'de tespit edilmiştir. Hartman ve ark. (2002), çimlenme için gerekli sıcaklık isteğinin türlere göre farklılık göstermekle birlikte optimum çimlenme sıcaklığının $15-30^{\circ} \mathrm{C}$ arasında değiştiğini belirtmişlerdir. Bununla birlikte, bazı dut türleri üzerinde gerçekleştirilen tohum çimlendirme çalışmalarında doğrudan $25^{\circ} \mathrm{C}$ kullanılmış ve çimlenme oranlarının M. nigra'da \%33 (Koyuncu, 2005), M. rubra, M. laevigata ile $M$. alba türlerinde \%9 ile \%66.5 (Gündüz ve ark., 2019) arasında değişim gösterdiği bildirilmiştir. Bu çalışmadan elde edilen çimlenme değerlerinin daha yüksek gerçekleşmesinin $20^{\circ} \mathrm{C}$ 'nin dutta çimlenme oranı için optimum sıcaklık olarak belirlenmesinin yanında tür ve genotiplerin farklılık göstermesinden kaynaklandığı söylenebilir.

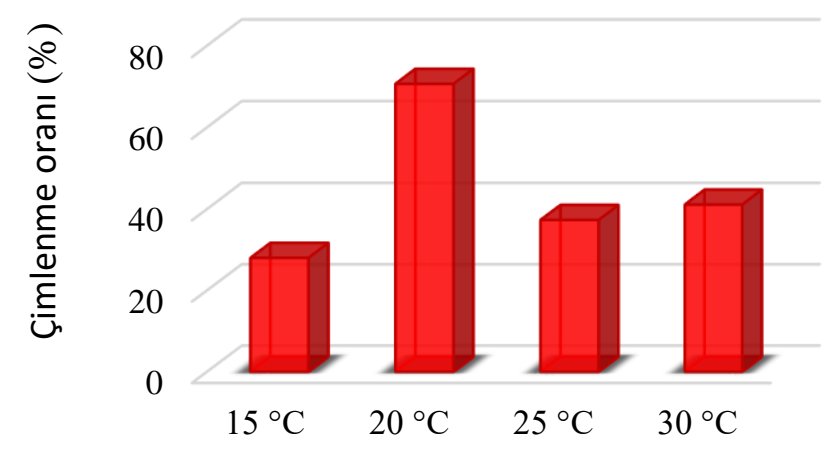

Şekil 1. Uygulama yapılmamış (kontrol) karadut tohumlarının farklı sıcaklıklardaki çimlenme oranları Figure 1. Germination rate of untreated (control) black mulberry seeds at different temperatures

Karadut tohumlarının çimlenmesi üzerine prolin uygulamalarının etkisi, çimlenme sıcaklıklarına göre değişkenlik göstermiştir. Prolin uygulamalarının $15^{\circ} \mathrm{C}^{\prime}$ de tutulan tohumların çimlenmesi üzerine istatistiksel olarak önemli seviyede bir etkisi belirlenmemiştir. Tohumlarda düşük sıcaklıkların, dokularda oksidatif strese neden olarak çimlenme oranını azalttığı bilinmektedir (Airaki ve ark., 2012). Bu bakımdan çalışmamızda $15^{\circ} \mathrm{C}$ gibi nispeten düşük sıcaklıkta prolin uygulamalarının çimlenme oranı üzerine etkisinin olmadığı tespit edilmiştir. Bu sıcaklıkta $\left(15^{\circ} \mathrm{C}\right)$ prolin uygulamalarından elde edilen çimlenme oranları (\%14.67 ile \%22.67 arasında) kontrole göre (\%28.00) daha düşük gerçekleşmiştir (Çizelge 1). Benzer olarak Burton ve Bazzaz (1991), kırmızı dut tohumlarının 5$10^{\circ} \mathrm{C}^{\prime}$ deki sıcaklıklarda çimlenmediğini; Singh ve Saratchandra $(2003)^{\prime}$ da $15^{\circ} \mathrm{C}^{\prime}$ nin altındaki ve $39^{\circ} \mathrm{C}^{\prime}$ nin üzerindeki sıcaklıkların tohum çimlenmesini engellediğini belirtmişlerdir. Bununla birlikte, $20^{\circ} \mathrm{C}^{\prime}$ de en yüksek çimlenme oranı (\%82.67) $5 \mathrm{mM}$ prolin 
uygulamasından elde edilirken, en düşük çimlenme oranı $1 \mathrm{mM}$ ve $15 \mathrm{mM}$ prolin uygulamalarından (sırasıyla, $\% 57.33$ ve \%58.67) alınmıştır. Prolin uygulanan tohumların $25^{\circ} \mathrm{C}^{\prime}$ de çimlendirilmesinde, tüm uygulamalar arasında, en yüksek çimlenme oranı \%93.33 ile $10 \mathrm{mM}$ prolin dozunda tespit edilmiştir. En düşük çimlenme ise kontrol'de (\%37.33) belirlenmiştir.
Sıcaklığın $30^{\circ} \mathrm{C}^{\prime}$ ye yükselmesiyle tohum çimlenmesinde bir azalma olduğu görülmüş, en yüksek çimlenme oranı 5 mM prolin uygulamasından (\%75.83) elde edilmiştir. Genel olarak değerlendirildiğinde, prolinin sıcaklık artışlarına bağlı olarak tohum çimlenmesini olumlu yönde etkilediği $\left(15^{\circ} \mathrm{C}\right.$ hariç) belirlenmiştir.

Çizelge 1. Çimlenme oranı (\%) üzerine sıcaklık ve prolin uygulamalarının etkileri

Table 1. Effects of temperature and proline applications on germination rate (\%)

\begin{tabular}{lcllll}
\hline Uygulama & Doz & $15^{\circ} \mathrm{C}$ & $20^{\circ} \mathrm{C}$ & $25^{\circ} \mathrm{C}$ & $30^{\circ} \mathrm{C}$ \\
\hline Kontrol & 0 & $28.00^{\circ \text { d }}$ & $70.67^{\text {od }}$ & $37.33 \mathrm{c}^{*}$ & $41.09^{\text {od }}$ \\
\hline \multirow{4}{*}{ Prolin } & $1 \mathrm{mM}$ & 22.67 & 57.33 & $65.33 \mathrm{~b}$ & 52.00 \\
& $5 \mathrm{mM}$ & 14.67 & 82.67 & $58.22 \mathrm{~b}$ & 75.83 \\
& $10 \mathrm{mM}$ & 12.39 & 65.06 & $93.33 \mathrm{a}$ & 62.67 \\
& $15 \mathrm{mM}$ & 20.00 & 58.67 & $68.00 \mathrm{~b}$ & 60.00 \\
\hline
\end{tabular}

*Aynı sütunda farklı harfle gösterilen ortalamalar arasındaki fark önemlidir $(p<0.05)$. öd: Önemli değil

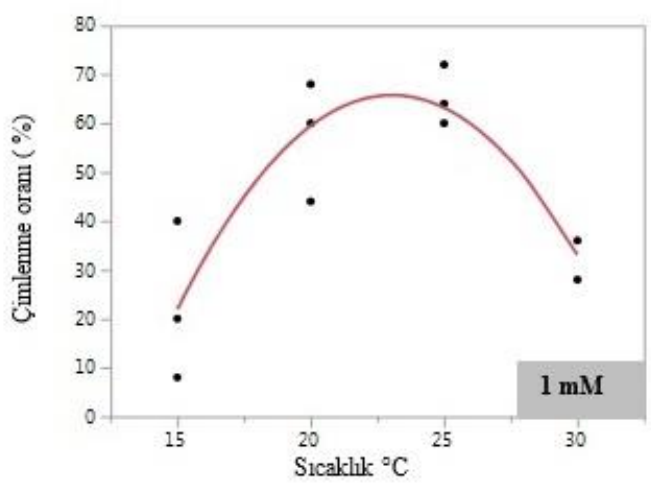

Çimlenme oramı $=28.438621+1.6638581 *$ g1cakllk$0.6764228 *$ (s1cakllk- 21.8182$)^{2}$

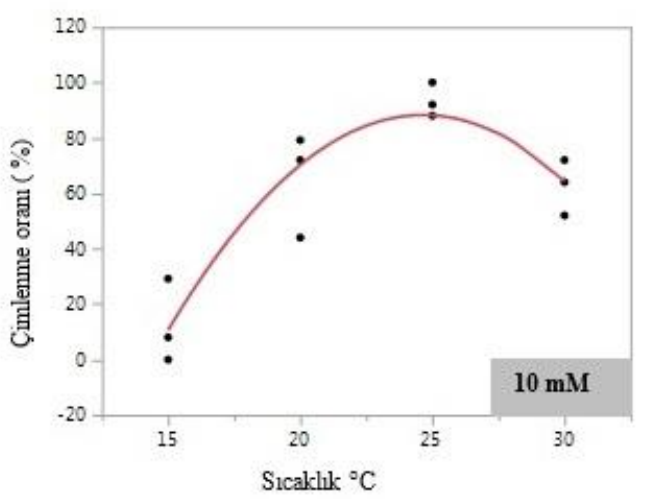

Çimlenme oranı $=3.8027778+3.5822222 *$ sıcaklık$0.8333333 *(\text { sıcaklık-22.5) })^{2}$

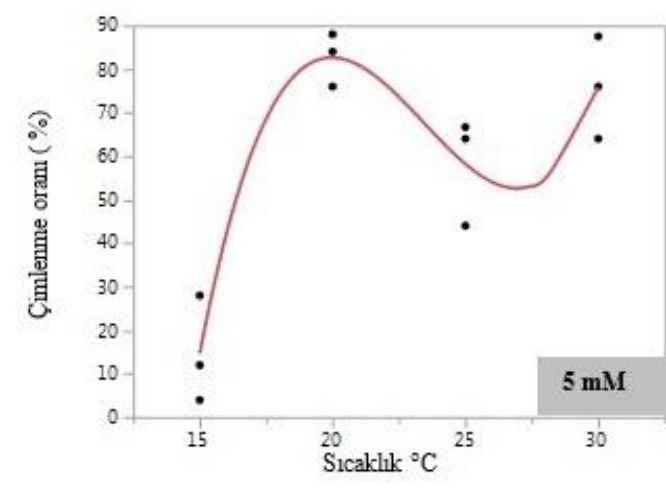

Çimlenme oram1 $=208.8125-6.0097222 *$ g1caklik$0.5038889 *$ (s1cakllk- 22.5$)^{2}+0.1793333^{*}$ (s1caklik- 22.5$)^{3}$

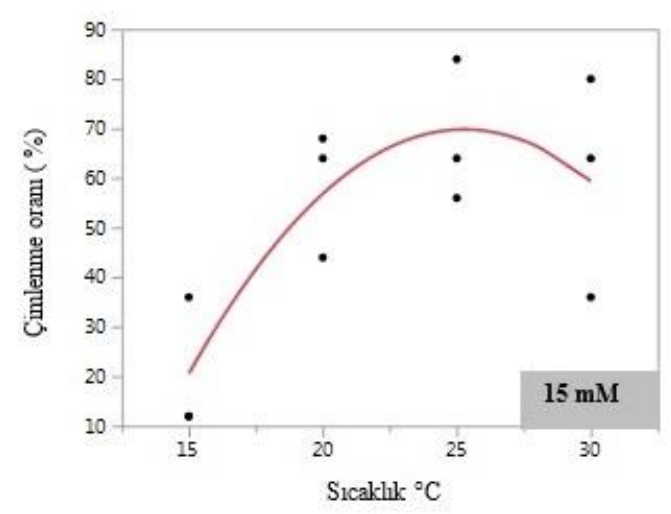

Çimlenme oranı $=8.05+2.5866667{ }^{*}$ sıcaklık$0.4666667^{*}(\text { sıcaklık-22.5) })^{2}$

Şekil 2. Prolin uygulamalarının farklı sıcaklık koşullarında çimlenme oranı üzerine etkileri Figure 2. Effects of proline applications on germination rate at different temperature conditions 
Bu sonuçların, prolinin bitki türlerine bağlı olarak sıcaklık, kuraklık ve tuz gibi stres faktörleri altında (Ghaffari ve Tadayon, 2018; Kaur ve Gupta, 2017; Singh ve ark., 2018) veya normal koşullarda (Sultana ve ark., 2000; Parcha, 2016) tohum çimlenmesini uyardığı ile ilgili araştırma sonuçlarıyla benzerlik gösterdiği söylenebilir. Ayrıca, Neto ve ark. (2004), sıcaklığın $30^{\circ} \mathrm{C}^{\prime}$ nin üzerine çıktığında prolinin tohumda çimlenmeyi yavaşlatarak ISı stresine karşı tohumu koruduğunu ve stres koşulları ortadan kalktığında çimlenmenin başladığını bildirmiştir.

Yapılan regresyon analizlerinde, kontrol dışındaki tüm prolin uygulamalarında quadratik model istatistiksel olarak önemli bulunmuştur. Regresyon analizlerinden elde edilen formüllere göre yapılan hesaplamalarda, 1 $\mathrm{mM}$ prolin uygulamasında max. çimlenme sıcaklığı 23.05, $10 \mathrm{mM}^{\prime}$ da $24.65^{\circ} \mathrm{C}$ ve $15 \mathrm{mM}$ dozunda $25.27^{\circ} \mathrm{C}$ olarak belirlenmiştir (Şekil 2).
Çimlenme süresi, türe göre değişmekle birlikte, nem, sıcaklık, ışık ve oksijen gibi çevresel faktörler tarafından etkilenmektedir (Bonner, 2008). Bu çalışmadan elde edilen ortalama çimlenme süresi, sıcaklıklara bağlı olarak 13.06 gün ile 16.61 gün arasında değişim göstermiştir.

Aruga (1994) ve Singh ve Saratchandra (2003)'nın da belirttikleri gibi sıcaklığın yükselmesiyle birlikte ortalama çimlenme süresinde genel bir azalma meydana gelmiştir (Şekil 3). Prolin uygulamalarının, ortalama çimlenme süresi üzerine etkisi ise önemsiz bulunmuştur. En yüksek sıcaklık derecesi olan $30^{\circ} \mathrm{C}$ 'de çimlenme 6 . günde başlamış ve 12 . günden sonra maksimuma ulaşmıştır. $15^{\circ} \mathrm{C}$ sıcaklıkta ise 14 . günden itibaren tohumlarda çimlenme başlamıştır. Benzer olarak Aruga (1994), dutta çimlenmenin $30^{\circ} \mathrm{C}$ de 8 . günde, $33^{\circ} \mathrm{C}$ ve $36^{\circ} \mathrm{C}^{\prime}$ de ise 6 . günde başlayabileceğini bildirmiştir. Genel olarak çimlenme oranı, $15^{\circ} \mathrm{C}$ hariç, tüm uygulamalarda 13 . ve 14. günlerde en yüksek değere ulaşmıştır.

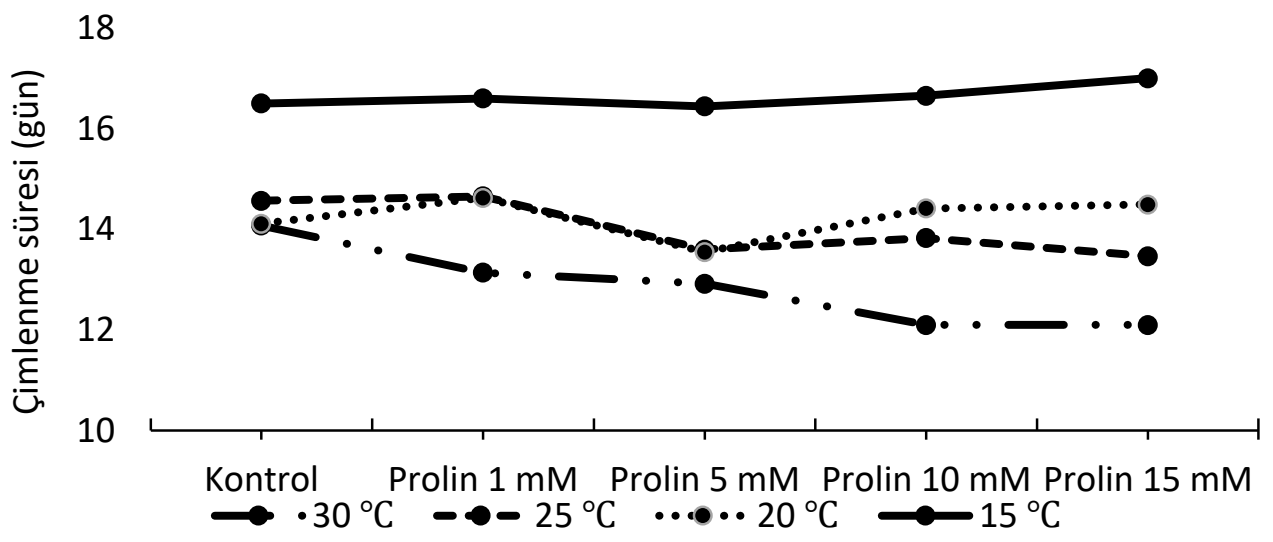

Şekil 3. Ortalama çimlenme süresi (gün) üzerine sıcaklık ve prolin uygulamalarının etkileri Figure 3. Effects of temperature and proline applications on average germination time (days)

Çizelge 3'de, sıcaklık uygulamalarının tohumların kökçük uzunluğunu kısmen etkilediği görülmektedir. Kontrol uygulamalarında sıcaklık artışına bağlı olarak nispeten bir artış olduğu, ancak prolin uygulamalarının $15^{\circ} \mathrm{C}, 20^{\circ} \mathrm{C}$ ve $30^{\circ} \mathrm{C}^{\prime}$ deki çimlenen tohumların kökçük uzunluğunu istatistiksel olarak etkilemediği belirlenmiştir. En uzun kökler, $25^{\circ} \mathrm{C}^{\prime}$ de $10 \mathrm{mM}$ prolin uygulamasından $(2.84 \mathrm{~mm})$ elde edilmiştir. En kısa kök uzunluğu ise $2.27 \mathrm{~mm}$ ile kontrolde tespit edilmiştir (Çizelge 2).

Çizelge 2. Kökçük uzunluğu $(\mathrm{mm})$ üzerine sıcaklık ve prolin uygulamalarının etkileri

Table 2. Effects of temperature and proline applications on root length $(\mathrm{mm})$

\begin{tabular}{lccccc}
\hline Uygulama & Doz & $15^{\circ} \mathrm{C}$ & $20^{\circ} \mathrm{C}$ & $25^{\circ} \mathrm{C}$ & $30^{\circ} \mathrm{C}$ \\
\hline Kontrol & 0 & $2.08^{\text {öd }}$ & $2.04^{\text {od }}$ & $2.27 \mathrm{~b}$ & $2.62^{\text {od }}$ \\
\hline \multirow{4}{*}{ Prolin } & $1 \mathrm{mM}$ & 2.00 & 2.19 & $2.33 \mathrm{ab}$ & 2.85 \\
& $5 \mathrm{mM}$ & 2.00 & 2.25 & $2.63 \mathrm{ab}$ & 2.86 \\
& $10 \mathrm{mM}$ & 2.00 & 3.22 & $2.84 \mathrm{a}$ & 2.88 \\
& $15 \mathrm{mM}$ & 2.00 & 2.14 & $2.64 \mathrm{ab}$ & 2.70
\end{tabular}

**Aynı sütunda farklı harfle gösterilen ortalamalar arasındaki fark önemlidir $(p<0.05)$. öd: Önemli değil 
Çimlenme ortamındaki sıcaklık artışı, çimlenen bitkilerin gelişimini de hızlandırmış, çimlenme süresinin sonunda özellikle $30^{\circ} \mathrm{C}$ sıcaklık uygulamasında, tohum kabukları düşmüş, çenek yapraklar ve hipokotil belirgin bir büyüklüğe erişmiştir (Şekil 4). Seçilen türlere göre çimlenme ve hipokotil oluşumunda bazı farklılıklar görülebilmektedir. Örneğin Pistacia lentiscus L. tohumları ile yapılan bir çalışmada, bu çalışma ile benzer biçimde en iyi çimlenme ve hipokotil oluşumu, $15 / 25^{\circ} \mathrm{C}$ sıcaklıklarda gözlenmiştir (Köse, 2001).

Sonuç olarak, karadutun vejetatif yolla çoğaltılmasında yaşanan zorluklar yanında ıslah çalışmalarında tohumun kullanılmasının önemi nedeniyle çimlenme çalışmaları oldukça kritiktir. Bu çalış̧ma ile karadutun çoğaltılmasında ve yeni bitki elde edilmesi için özellikle tohum kaynaklı sorunlara çözüm önerisi getirilmeye çalışımıştır. Pratikte karadut, beyaz dut üzerine aşılanarak çoğaltılmaya çalışılmakta, ancak bu iki tür arasında aşı uyuşmazlığının bulunduğu bildirilmektedir. Karadut çöğürlerinin fidan üretiminde kullanılması ve son yıllarda artan melezleme ıslahı çalışmalarında melez bitkilerin elde edilmesi, tohumla çoğaltma başarısına bağlıdır. Bu çalışmada, karadut tohumlarında standart çimlendirme için $20^{\circ} \mathrm{C}^{\prime}$ nin daha başarılı sonuçlar verdiği saptanmıştır. Ayrıca, tohum kaybını azaltmak ve çimlenme oranını artırmak için en yüksek çimlenme oranının $10 \mathrm{mM}$ prolin uygulanan tohumların $25^{\circ} \mathrm{C}^{\prime} \mathrm{de}$ çimlenmesinden elde edildiği tespit edilmiştir.

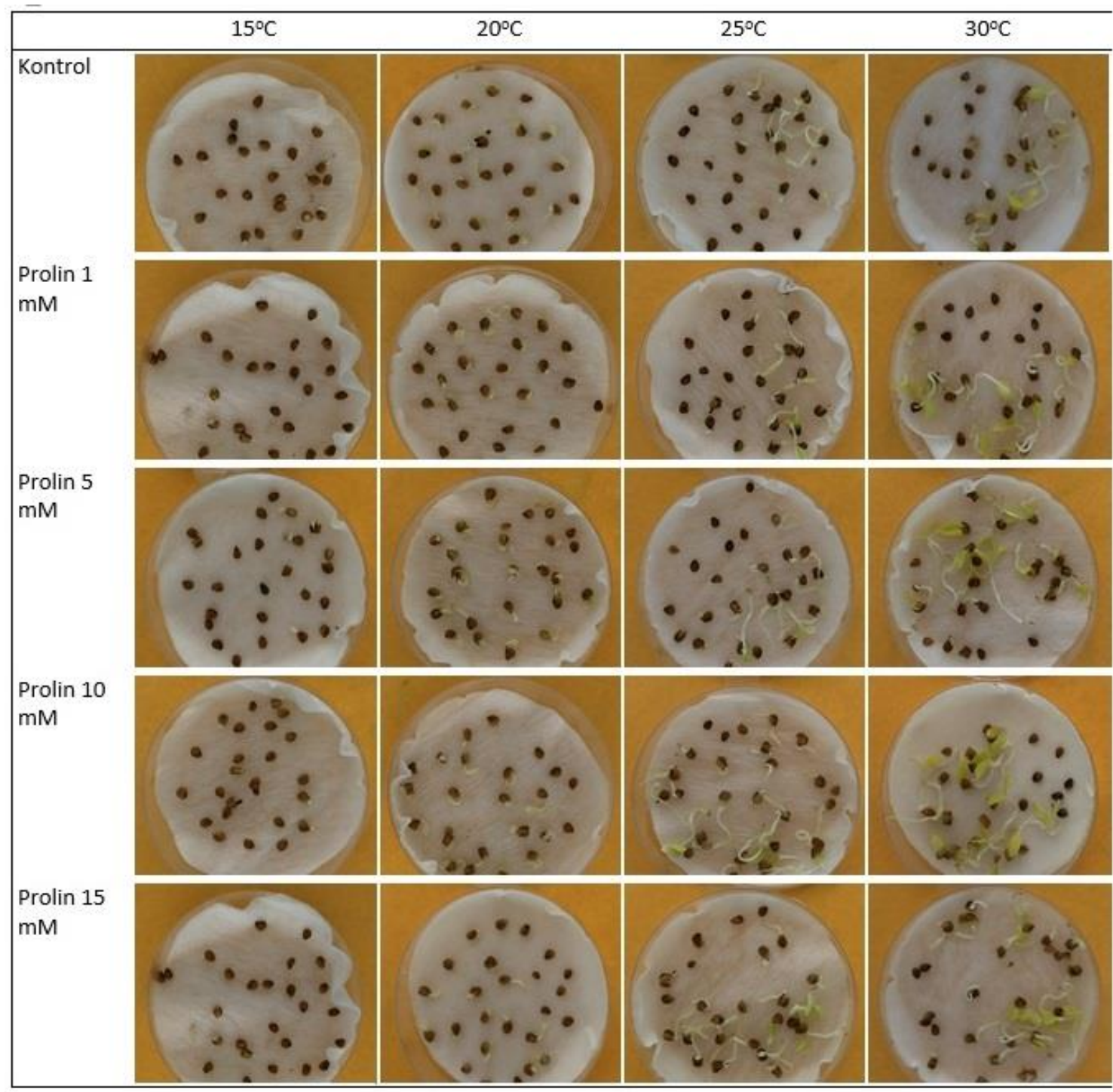

Şekil 4. Sıcaklık $\left({ }^{\circ} \mathrm{C}\right)$ ve prolin $(\mathrm{mM})$ uygulamaları sonrasında çimlenmiş tohumların görünümü Figure 4. The appearance of germinated seeds after temperature $\left({ }^{\circ} \mathrm{C}\right)$ and proline $(\mathrm{mM})$ applications 
ÖZET

Amaç: Karadut (Morus nigra), vejetatif ve generatif olarak çoğaltılması zor bir türdür. Bu nedenle tohumlarının daha kolay çimlenebilmesi için araştırmacılar tarafından farklı uygulamalar yapılmaktadır. Bu çalışmada da farklı sıcaklık koşullarında prolin uygulamalarının, karadut tohumlarının çimlenmesi üzerine etkilerinin belirlenmesi amaçlanmıştır.

Yöntem ve Bulgular: Çimlenmeyi teşvik etmek amacıyla tohumlar, $1 \mathrm{mM}, 5 \mathrm{mM}, 10 \mathrm{mM}$ ve $15 \mathrm{mM}$ prolin çözeltilerinde, kontrol grubunda ise suda olmak üzere 24 saat süre ile oda sıcaklığında bekletilmişlerdir. Bu sürenin sonunda steril petrilere, 3 tekerrürlü ve her tekerrürde 25 adet olacak şekilde yerleştirilmişlerdir. Tohum çimlendirme çalışmaları karanlık koşullarda $15^{\circ} \mathrm{C}, 20^{\circ} \mathrm{C}$, $25^{\circ} \mathrm{C}$ ve $30^{\circ} \mathrm{C}$ sıcaklıklardaki bitki büyüme kabinlerinde gerçekleştirilmiştir. 17 günlük çimlenme süresi sonunda kontrol grubundaki tohumlarda çimlenme oranı, \%28 ile \%70.67 arasında değişim göstermiş, en yüksek çimlenme oranı $20^{\circ} \mathrm{C}^{\prime}$ de elde edilmiştir. Prolin uygulamalarında, en yüksek çimlenme oranı \%93.33 ile $10 \mathrm{mM}$ prolin uygulamasında ve $25^{\circ} \mathrm{C}^{\prime}$ de bekletilen tohumlarda belirlenmiştir. Genel olarak çimlenme oranı, $15^{\circ} \mathrm{C}$ hariç, tüm uygulamalarda 13. ve 14. günlerde en yüksek değere ulaşmıştır.

Genel Yorum: Bu çalışmada, herhangi bir uygulama yapılmadan karadut tohumlarının $20^{\circ} \mathrm{C}^{\prime}$ de yüksek oranda çimlendiği tespit edilmiştir. Bu oran, $25^{\circ} \mathrm{C}^{\prime}$ de 10 $\mathrm{mM}$ prolin uygulamasıyla \%90'ın üzerine çıkmıştır.

Çalışmanın Önemi ve Etkisi: Karadut çöğürlerinin fidan üretiminde kullanılması ve son yıllarda artan melezleme ıslahı çalışmalarında melez bitkilerin elde edilmesi, tohumla çoğaltma başarısına bağlıdır. Çalışma ile tohum kaybının azaltılması ve çimlenme oranının artırılmasında $25^{\circ} \mathrm{C} 10 \mathrm{mM}$ prolin uygulaması oldukça başarılı bulunmuştur.

Anahtar Kelimeler: Morus nigra, dinlenme, prolin, tohum çimlenme oranı

\section{ÇIKAR ÇATIŞMA BEYANI}

Yazarlar çalışma konusunda çıkar çatışmasının olmadığını beyan eder.

\section{ARAŞTIRMACILARIN KATKI ORANI BEYANI}

Yazarlar çalışmaya eşit oranda katkı sağlamış olduklarını beyan eder.

\section{KAYNAKLAR}

Ağaoğlu YS, Çelik H, Çelik M, Fidan Y, Gülşen Y, Günay A, Halloran N, Köksal I, Yanmaz R (2001) Genel Bahçe Bitkileri. Ankara Üniv. Ziraat Fak. Eğitim, Araş. ve Geliş. Vakfı Yay. No: 5, Ankara. 369s.

Airaki M, Leterrier $M$, Mateos RM, Valderrama R, Chaki M, Barroso JB, Del Rio LA, Palma JM, Corpas FJ (2012) Metabolism of reactive oxygen species and reactive nitrogen species in pepper (Capsicum annuum L.) plants under low temperature stress. Plant, Cell and Env. 35: 281-295.

Al Absi KM (2010) The effects of different pre-sowing seed treatments on breaking the dormancy of mahaleb cherries, Prunus mahaleb L. seeds. Seed Sci. and Tech. 38: 332-340.

Aliniaeifard S, Hajilou J, Tabatabaei SJ (2016) Photosynthetic and growth responses of olive to proline and salicylic acid under salinity condition. Not. Bot. Horti Agrobo 44: 579-585.

Aruga H (1994) Principles of Sericulture. A.A. Balkema/Rotterdam. pp 367.

Aulifa DL, Fitriansyah SN, Ardiansyah SA, Wibowo DP, Julata YA, Christy DS (2017) Phytochemical screening, antibacterial activity, and mode of action on Morus nigra. Pharmacognosy J. 10: 167-171.

Bewley JD, Black M (1994) Seeds: Physiology of Development and Germination. Plenum Pres, New York. pp 445.

Bonner FT (2008) Seed biology, In: The Woody Plant Seed Manuel. Agriculture Handbook 727 (Eds. Bonner FT and Karrfalt RP), United States Department of Agriculture, Forest Service, USA. pp 3-38.

Bozdoğan O, Karaman Y, Uyar F, Evli S, Akkaya F, Tursun N (2018) Rumex crispus L. (kıvircık labada) tohumlarındaki dormansinin kırılmasında farklı uygulama yöntemlerinin etkileri. Mustafa Kemal Üni. Zir. Fak. Der. 23: 188-196.

Burton PJ, Bazzaz FA (1991) Tree seedling emergence on interactive temperature and moisture gradients and in patches of old-field vegetation. Amer. J. Bot. 78: 131-149.

Chang JC (2008) 'Miaoli No. 1' mulberry: a new cultivar for berry production. HortSci. 43: 1594-1595.

Çalışkan O, Mavi K, Polat AA (2012) Influences of presowing treatments on the germination and emergence of fig seeds (Ficus carica L.). Acta Sci. Agro. Mar. 34: 293-297.

El Obeidy AA (2005) Flowering and fruiting of cv. Pakistan mulberry under saline soil conditions in Egypt. Fruits 60: 405-411. 
Ercişli S (2004) A short review of the fruit germplasm resources of Turkey. Genet. Resour. Crop Evol. 51: 419-435.

Ercişli S, Orhan E (2007) Chemical composition of white (Morus alba), red (Morus rubra) and black (Morus nigra) mulberry fruits. Food Chem. 103: 1380-1384.

Erdoğan V, Aygün A (2006). Karadut'un (Morus nigra L.) yeşil çelikle çoğlatılması üzerinde bir araştırma. II Ulusal Üzümsü Meyveler Sempozyumu, 14 - 16 Eylül, Tokat, ss. 172-175.

Gerçekçioğlu R, Çekiç Ç (1999) Mahlep (Prunus mahaleb L.) tohumlarının çimlenmesi üzerine bazı uygulamaların etkileri. Tr. J. of Agri. and For. 23: 145150.

Ghaffari H, Tadayon MR (2018) Effect of proline on seed germination indices of Castile sugar beet cultivar seed germination criteria under drought stress. Iranian J. Seed Sci. and Tech. 7: 171-182.

Gosling P (2007) Raising Trees and Shrubs from Seed. Forestry Commission 231 Corstorphine Road Edinburgh. pp 28.

Gündüz K, Karaat FE, Uzunoğlu F, Mavi K (2019) Influences of pre-sowing treatments on the germination and emergence of different mulberry species seeds. Acta Sci. Pol. Hort. Cult. 18: 97-104.

Hartmann HT, Kester DE, Davies FT, Geneve RL (2002) Plant Propagation: Principles and Practices. 7th ed. : Prentice Hall, New Jersey. pp 880.

Hayat S, Hayat $Q$, Alyemeni MN, Wani AS, Pichtel J, Ahmad A (2012) Role of proline under changing environments: a review. Plant Sig. and Beh. 7: 1-11.

Kaur G, Asthir B (2015) Proline: a key player in plant abiotic stress tolerance. Biol. Plant. 59: 609-619.

Kaur H (2017) Influence of proline and ascorbic acid on seed germination behavior of tomato (Solanum lycopersicum L.) under salt stress. MSc Thesis, Punjab Agri. Univ., 61 p.

Kaur S, Gupta N (2017) Effect of proline and salicylic acid on germination and antioxidant enzymes at different temperatures in muskmelon (Cucumis melo L.) seeds. J. of App. and Nat. Sci. 9: 2165-2169.

Kavi Kishor PB, Hima Kumari P, Sunita MSL, Sreenivasulu N (2015) Role of proline in cell wall synthesis and plant development and its implications in plant ontogeny. Front. Plant Sci. 6:544.

Koyuncu $F$ (2005) Breaking seed dormancy in black mulberry (Morus nigra L.) by cold stratification and exogenous application of gibberellic acid. Acta Biol. Crac. Ser. Bot. 47: 23-26.
Köse H (2001) Doğal bitki örtüsünde bulunan bazı odunsu süs bitkilerinin tohum çimlendirme yöntemleri üzerinde araştırmalar IV. Pistacia lentiscus L. (sakız ağacı). Anadolu Der. 11: 1-13.

Mattioli R, Costantino P, Trovato M (2009) Proline accumulation in plants, not only stress. Plant Sig. \& Beh. 4: 1016-1018.

Neto NBM, Custosio CC, Gatti AB, Priolli MR, Jose V, Cardoso M (2004) Proline: use as an indicator of temperature stress in bean seeds. Crop Breed. and App. Bio. 4: 330-337.

Parcha D (2016) Effect of seed treatment with proline ad salicylic acid on germination in tinda (Citrullus vulgaris L.) cv. S-48 at different temperatures. MSc Thesis, Punjab Agri. Univ., 74p.

Rodrigues EL, Marcelino G, Silva GT, Figueiredo PS, Garcez WS, Corsino J, Guimaraes RCA, Freitas C (2019) Nutraceutical and medicinal potential of the Morus species in metabolic dysfunctions. Int. J. Mol. Sci. 20 (2): 1-16.

Schwacke R, Grallath S, Breitkreuz KE, Stransky H, Frommer WB, Rentsch D (1999) LeProT1, a transporter for proline, glycine betaine and $\mathrm{Y}$-amino butyric acid in tomato pollen. Plant Cell 11:377-91.

Singh M, Singh A, Nehal N, Sharma N (2018) Effect of proline on germination and seedling growth of rice (Oryza sativa L.) under salt stress. J. of Phar. and Phyto. 7: 2449-2452.

Singh T, Saratchandra B (2003) Principles and Techniques of Silkworm Seed Production. Discovery Publishing House, New Delhi, India. pp 376.

Sultana N, Ikeda T, Mitsui T (2000) GA3 and proline promote germination of wheat seeds by stimulating $\alpha$-amylase at unfavorable temperatures. Plant Pro. Sci. 3: 232-237.

Türemiş N, Pırlak L, Eşitken A, Erdoğan Ü, Tümer A, İmrak B, Burgut A (2017) A field survey of promising mulberry (Morus spp.) genotypes from Turkey. Erwerbs-Obstbau 59: 101-107.

Vijayan K, Srivastava PP, Raju PY, Saratchandra B (2012) Breeding for higher productivity in mulberry. Czech J. Genet. Plant Breed. 48: 147-156.

Yıldız K, Çekiç Ç, Güneş M, Özgen M, Özkan Y, Akça Y, Gerçekçioğlu R (2009) Farklı dönemlerde alınan karadut (Morus nigra L.) çelik tiplerinde köklenme başarısının belirlenmesi. Goü. Zir. Fak. Der. 26: 1-5. 